NBER WORKING PAPER SERIES

\title{
AGENCY PROBLEMS AND DIVIDEND POLICIES AROUND THE WORLD
}

\author{
Rafael La Porta \\ Florencio Lopez-de-Silanes \\ Andrei Shleifer \\ Robert W. Vishny
}

\author{
Working Paper 6594 \\ http://www.nber.org/papers/w6594 \\ NATIONAL BUREAU OF ECONOMIC RESEARCH \\ 1050 Massachusetts Avenue \\ Cambridge, MA 02138 \\ June 1998
}

The authors are from Harvard University, Harvard University, Harvard University, and University of Chicago, respectively. They are grateful to Alexander Aganin for excellent research assistance, and to Lucian Bebchuk, Mihir Desai, Edward Glaeser, Denis Gromb, Oliver Hart, James Hines, Kose John, James Poterba, Roberta Romano, Raghu Rajan, Daniel Wolfenzohn, and Luigi Zingales for helpful comments. This work has been supported by a grant from the National Science Foundation to the National Bureau of Economic Research. Any opinions expressed are those of the author and not those of the National Bureau of Economic Research.

(C) 1998 by Rafael La Porta, Florencio Lopez-de-Silanes, Andrei Shleifer, and Robert W. Vishny. All rights reserved. Short sections of text, not to exceed two paragraphs, may be quoted without explicit permission provided that full credit, including $\mathbb{C}$ notice, is given to the source. 
Agency Problems and Dividend

Policies Around the World

Rafael La Porta, Florencio Lopez-de-Silanes, Andrei Shleifer and Robert W. Vishny

NBER Working Paper No. 6594

June 1998

JEL No. 632, 635

\section{ABSTRACT}

This paper addresses the question of why firms pay dividends, the so-called "dividend puzzle" from the agency perspective. We outline two agency models of dividends. On what we call "the outcome" model, dividends are the result of effective pressure by minority shareholders to force corporate outsiders to disgorge cash. Under this model, stronger minority shareholder rights should be associated with higher dividends. On what we call "the substitute" model, insiders choose to pay dividends to establish a reputation for decent treatment of minority shareholders so that firms can raise equity finance in the future. Under this model, stronger minority shareholder rights reduce the need for establishing a reputation, and so should be associated with lower dividends. We compare these models on a cross-section of 4,000 companies from around the world, which operate in 33 countries with different levels of shareholder protection, and therefore different strength of minority shareholder rights. The findings on payout levels and other results support the outcome agency model of dividends.

\author{
Rafael La Porta \\ Department of Economics \\ Harvard University \\ Cambridge, MA 02138 \\ and NBER
}

Florencio Lopez-de-Silanes

Kennedy School of Government

Harvard University

79 JFK Street

Cambridge, MA 02138

and NBER

f_lopezdesilanes@harvard.edu

Robert W. Vishny

Graduate School of Business

The University of Chicago

1101 E. 58th Street

Chicago, IL 60637

and NBER

vishny@gsb.uchicago.edu 
I. Introduction.

The so-called dividend puzzle (Black 1976) has preoccupied the attention of financial economists at least since Modigliani and Miller's $(1958,1961)$ seminal work. This work established that, in a frictionless world, when the investment policy of a firm is held constant, its dividend payout policy has no consequences for shareholder wealth. Higher dividend payouts lead to lower retained earnings and capital gains, and vice versa, leaving total wealth of the shareholders unchanged. Contrary to this prediction, however, corporations follow extremely deliberate dividend payout strategies (Lintner 1956). This is the first element of the puzzle: how do firms choose their dividend policies?

In the United States, the puzzle is even deeper, since dividends entail rather draconian income tax consequences for the shareholders who receive them. The magnitude of the tax burden on dividends has given rise to a significant debate, which we briefly discuss below and try to address in our empirical work (e.g., Poterba and Summers 1985). A recent comprehensive survey of tax and other issues related to dividend policy is Allen and Michaely (1997).

Economists have proposed a number of explanations of the dividend puzzle. Of these, particularly popular is the idea that firms can signal future profitability by paying dividends (Bhattacharya 1979, John and Williams 1985, Miller and Rock 1985, Ambarish, John, and Williams 1987). Empirically, this theory had considerable initial success, since firms that initiate (or raise) dividends experience share price increases, and the converse is true for firms that eliminate (or cut) dividends (Aharony and Swary 1980, Asquith and Mullins 1983). Recent results are more mixed, since current dividend changes do not help predict firms' future earnings growth (DeAngelo, DeAngelo, and Skinner 1996 and Benartzi, Michaely, and Thaler 1997). 
Another idea, which has received only limited attention until recently (e.g., Easterbrook 1984, Jensen 1986, Fluck 1995, 1998, Myers 1996, Gomes 1996), is that dividend policies address agency problems between corporate insiders and outside shareholders. According to these theories, unless profits are paid out to shareholders as dividends, they may be diverted by the insiders for personal use or committed to unprofitable projects that provide private benefits for the insiders. As a consequence, outside shareholders have a preference for dividends over retained earnings. Theories differ on how outside shareholders actually get firms to disgorge cash. The key point, however, is that failure to disgorge cash leads to its diversion or waste, which is detrimental to outside shareholders' interest.

The agency approach moves away from the assumptions of the Modigliani-Miller theorem by recognizing two points. First, the investment policy of the firm cannot be taken as independent of its dividend policy, and, in particular, paying out dividends may reduce the inefficiency of marginal investments. Second, and more subtly, the allocation of all the profits of the firm to shareholders on a pro-rata basis cannot be taken for granted, and in particular the insiders may get preferential treatment through asset diversion, transfer prices and theft, even holding the investment policy constant. In so far as dividends are paid on a pro-rata basis, they benefit outside shareholders relative to the alternative of expropriable retained earnings.

In this paper, we attempt to identify some of the basic elements of the agency approach to dividends, to understand its key implications, and to evaluate them on a cross-section of over 4,000 firms from 33 countries around the world. The reason for looking around the world is that the severity of agency problems to which minority shareholders are exposed differs greatly across countries, in part because legal protections these shareholders have vary (La Porta et al. 1997, 
1998). Empirically, we find that dividend policies vary across legal regimes in ways consistent with a particular version of the agency theory of dividends. Specifically, firms in common law countries, where investor protection is typically better, make higher dividend payouts than firms in civil law countries do. Moreover, in common but not civil law countries, high growth firms make sharply lower dividend payouts than low growth firms. These results support the version of the agency theory in which investors in good legal protection countries use their legal powers to extract dividends from firms, especially when reinvestment opportunities are poor.

Section II of the paper summarizes some of the theoretical arguments. Section III describes the data. Section IV presents our empirical findings. Section V concludes.

II. Theoretical Issues.

Agency Problems and Legal Regimes

Conflicts of interest between corporate insiders, such as managers and controlling shareholders, on the one hand, and outside investors, such as minority shareholders, on the other hand, are central to the analysis of the modern corporation (Berle and Means 1932, Jensen and Meckling 1976). The insiders who control corporate assets can use these assets for a range of purposes that are detrimental to the interests of the outside investors. Most simply, they can divert corporate assets to themselves, through outright theft, dilution of outside investors through share issues to the insiders, excessive salaries, asset sales to themselves or other corporations they control at favorable prices, or transfer pricing with other entities they control (see Shleifer and Vishny 1997 for a discussion). Alternatively, insiders can use corporate assets to pursue investment strategies that yield them personal benefits of control, such as growth or 
diversification, without benefitting outside investors (e.g., Baumol 1959, Jensen 1986).

What is meant by insiders varies from country to country. In the United States, UK, Canada, and Australia, where ownership in large corporations is relatively dispersed, most large corporations are to a significant extent controlled by their managers. In most other countries, large firms typically have shareholders that own a significant fraction of equity, such as the founding families (La Porta, Lopez-de-Silanes, and Shleifer 1998). The controlling shareholders can effectively determine the decisions of the managers (indeed, managers typically come from the controlling family), and hence the problem of managerial control per se is not as severe as it is in the rich common law countries. On the other hand, the controlling shareholders can implement policies that benefit themselves at the expense of minority shareholders. Regardless of the identity of the insiders, the victims of insider control are minority shareholders. It is these minority shareholders that would typically have a taste for dividends.

One of the principal remedies to the agency problems is the law. Corporate and other law gives outside investors, including shareholders, certain powers to protect their investment against expropriation by insiders. These powers in the case of shareholders range from the right to receive the same per share dividends as the insiders, to the right to vote on important corporate matters, including the election of directors, to the right to sue the company for damages. The very fact that these legal protections exist probably explains why becoming a minority shareholder is a viable investment strategy at all, as opposed to just being an outright giveaway of money to strangers who are under few if any obligations to give it back.

As pointed out by La Porta et al. (1998), the extent of legal protection of outside investors differs enormously across countries. Legal protection consists of both the content of the laws and 
the quality of their enforcement. Some countries, including most notably the wealthy common law countries such as the US and the UK, provide effective enough protection of minority shareholders that the outright expropriation of corporate assets by the insiders is rare. Agency problems manifest themselves primarily through non-value-maximizing investment choices. In many other countries, the condition of outside investors is a good deal more precarious, but even there some protections do exist. La Porta et al. (1998) show in particular that common law countries appear to have the best legal protections of minority shareholders, whereas civil law countries, and most conspicuously the French civil law countries, have the weakest protections. Moreover, the quality of investor protection is reflected in both ownership concentration in firms (La Porta et al. 1998, La Porta, Lopez-de-Silanes, and Shleifer 1998), and in the valuation and breadth of capital markets across countries (La Porta et al. 1997). In sum, equilibrium agency costs vary across countries, and the legal system is a good proxy for these costs.

Agency and Dividends: Two Views

In a world of significant agency problems between corporate insiders and outsiders, dividends can play a useful role. By paying dividends, insiders return corporate earnings to investors and hence are no longer capable of using these earnings to benefit themselves. Dividends (a bird in hand) are better than retained earnings (a bird in the bush), since the latter might never materialize as future dividends (can fly away). In addition, the payment of dividends exposes companies to the possible need to come to the capital markets in the future to raise external funds, and hence gives outside investors an opportunity to exercise some control over the insiders at that time (Easterbrook 1984). 
Unfortunately, there are no fully satisfactory theoretical agency models of dividends that derive dividend policies as an outcome of some broad optimal contract between investors and corporate insiders, which allows for a range of feasible financing instruments. Instead, different models, such as Fluck (1995, 1998), Myers (1996), and Gomes (1996), capture different aspects of the problem. Moreover, the existing agency models have not yet fully dealt with the issues of choice between debt and equity in addressing agency problems, the choice between dividends and share repurchases, and the relationship between dividends and new share issues. We attempt to distill from the available literature the basic mechanisms of how dividends can be used to deal with agency problems. In particular, we distinguish two very different agency "models" of dividends. The predictions of these models that we test are necessarily limited by the fact that we do not look at all the financing and payout choices simultaneously.

Perhaps most importantly in this regard, we do not examine share repurchases, which have been commonly taken as the crucial alternative to paying dividends. We note, however, that from an examination of some limited evidence, we have discovered that share repurchases are most common precisely in the countries where firms pay high dividends as well, such as the US and the UK. In some civil law countries, share repurchases are even illegal. In a crosssection of countries, then, share repurchases appear to be complementary to dividends, rather than a substitute for them. If this is the case more generally, our evidence only underestimates the difference in total cash payouts to shareholders between civil and common law countries.

\section{Dividends as an Outcome of Legal Protection of Shareholders}

Under the first view, dividends are an outcome of an effective system of legal protection 
of shareholders. Under an effective system, minority shareholders use their legal powers to force companies to disgorge cash, thus precluding insiders from using too high a fraction of company earnings to benefit themselves ${ }^{2}$. Shareholders might do so by voting for directors who offer better dividend policies, by selling shares to potential hostile raiders who then gain control over non-dividend paying companies, by suing companies that do not pay dividends and instead spend funds on projects that only benefit the insiders, and so on. In addition, good investor protection makes asset diversion legally riskier and more expensive to the insiders, thereby raising the relative attraction of dividends even to them. The greater the rights of the minority shareholders, the more cash they will extract from the company, other things equal. In a cross-section of countries with different quality of shareholder protection, this implication is testable.

There is one further implication of this theory. Consider a country with good shareholder protection, and compare two companies in that country: one with good investment opportunities and growth prospects, and another with poor opportunities. Shareholders who feel protected would accept low dividend payouts, and high reinvestment rates, from a company with good opportunities, since they know that when this company's investments pay off, they could extract high dividends. In contrast, a mature company with poor investment opportunities would not be allowed to invest unprofitably. As a consequence, with good shareholder protection, high growth companies should have significantly lower dividend payouts than low growth companies. On the other hand, if shareholder protection is poor, we would not necessarily expect such a relationship between payouts and growth since shareholders may try to get what they can -- which may not be

${ }^{2}$ Even under an effective system, residual agency problems must remain, for if they are totally resolved, we are back to the world of Modigliani and Miller with no reason for dividends. 
much -- immediately. This also is a testable implication ${ }^{3}$. The implications of the outcome agency model of dividends are illustrated in Figure 1.

\section{Figure 1: Outcome Model of Dividends}

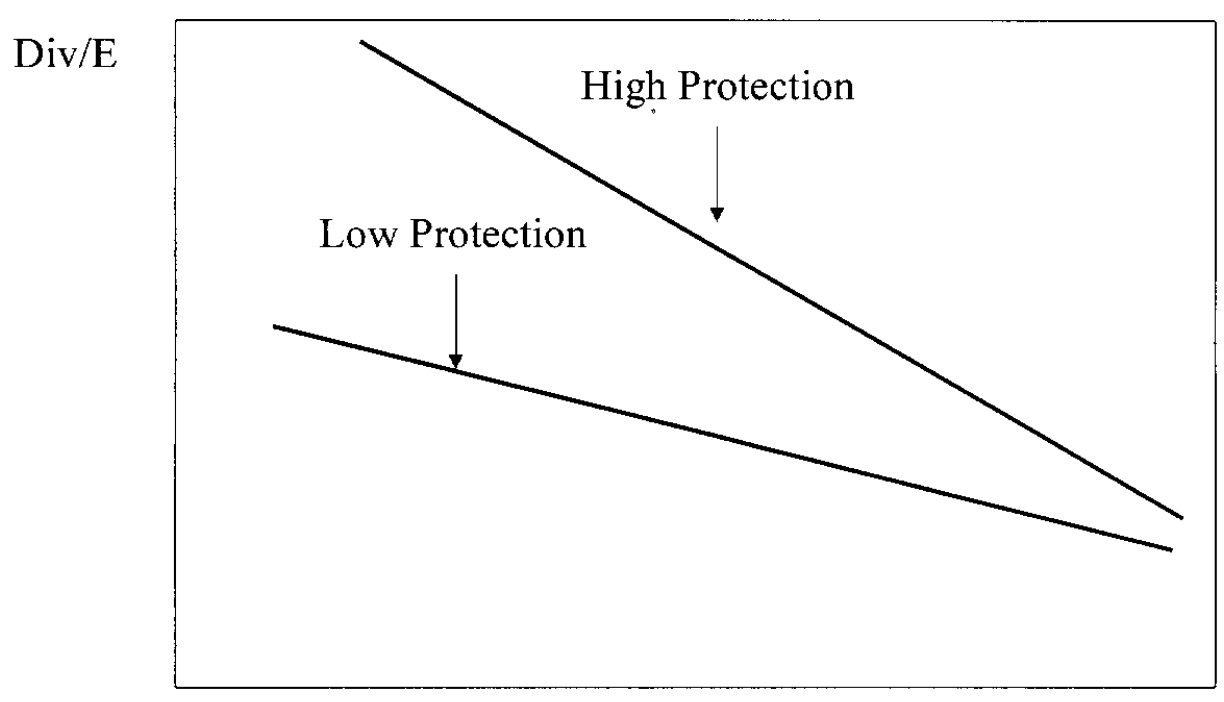

Growth in Sales

\section{Dividends as a Substitute for Legal Protection of Shareholders}

On an alternative agency view, dividends are a substitute for legal protection (Gomes 1996). This view relies crucially on the need for firms to come to the external capital markets for funds, at least occasionally. To be able to raise external funds on attractive terms, a firm must establish a reputation for moderation in expropriating shareholders. One way to establish such a reputation is by paying dividends, which reduce what is left inside the firm to expropriate. Such a reputation is worth the most in countries with weak legal protection of minority shareholders,

${ }^{3}$ Ambarish, John, and Williams (1987) derive the negative relationship between growth and payouts in a dividend signalling model. They do not focus on how this relationship would vary depending on how well shareholders are protected. In principle, this extension is possible. 
who have little else to rely on. As a consequence, the need for dividends to establish a reputation is the greatest in such countries. In countries with stronger shareholder protection, in contrast, the need for a reputational mechanism is weaker, and hence so is the need to pay dividends. This view implies that, other things equal, dividend payout ratios should be higher in countries with weak legal protection of shareholders than in those with strong protection ${ }^{4}$.

On this view, firms with better growth prospects also have a stronger incentive to establish a reputation since they have a greater potential need for external finance, other things equal. As a result, firms with better growth prospects might choose higher dividend payout ratios than firms with poor growth prospects. At the extreme, a firm that does not believe that it will ever need to raise external finance, and that operates in a country where investors have no rights at all, has no reason to pay any dividends. However, firms with good growth prospects also have a better current use of funds than firms with poor growth prospects. The relationship between growth prospects and dividend payout ratios is therefore ambiguous. Figure 2 illustrates the implications of this substitute agency model of dividends.

${ }^{4}$ Dewenter and Warther (1998) argue that there is less need to signal future earnings with dividends in Japan than in the US. This may be because Japanese firms have better ways of information transmission to the relevant investors than the US firms, or because Japanese managers are more insulated from investor pressure (Kang and Stulz 1996). Dewenter and Warther find that share price reactions to dividend changes are smaller in Japan than in the US. This finding may be consistent with either of the two agency models of dividends. 


\section{Figure 2: Substitute Model of Dividends}

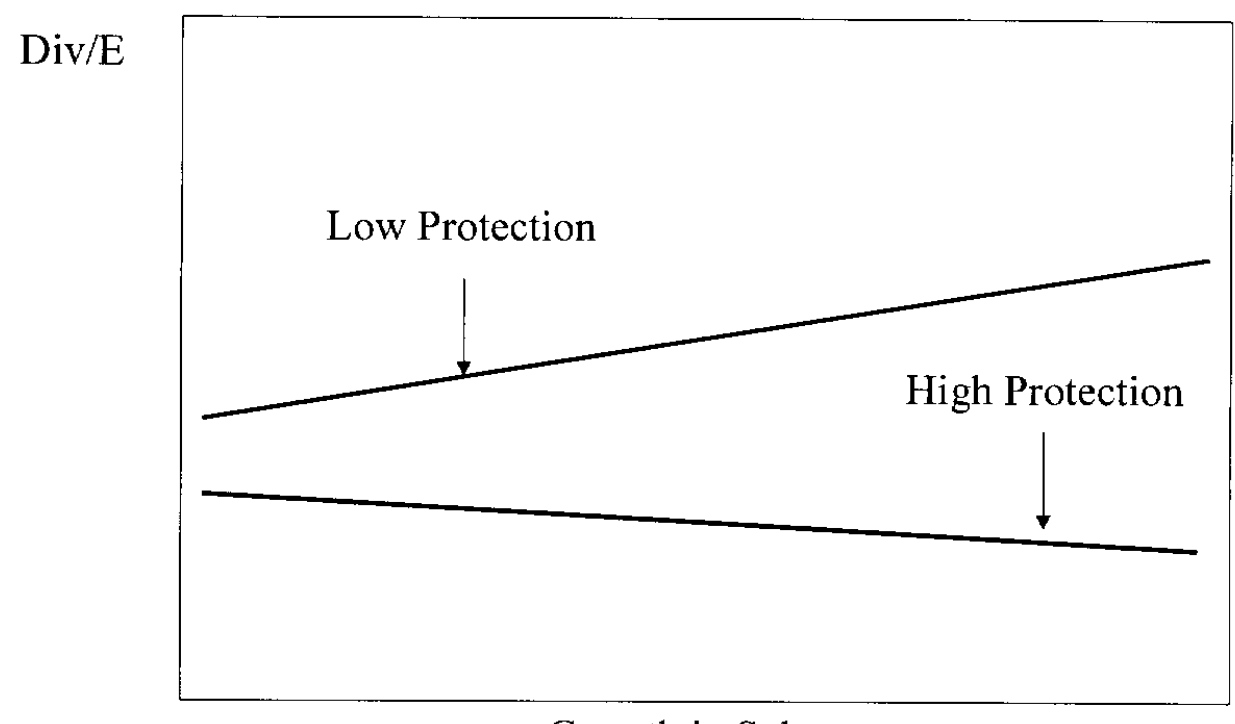

Growth in Sales

\section{Summary of Predictions of Agency Models}

We refer to the two alternative agency models of dividends as "the outcome model" and "the substitute model." The outcome model predicts that dividend payout ratios are higher in countries with good shareholder protection, other things equal. The substitute model predicts the opposite. The outcome model further predicts that, in countries with good shareholder protection, higher growth companies should have lower dividend payout ratios. The substitute model does not make this prediction. In fact, it makes a weak prediction that, in countries with poor shareholder protection, higher growth firms might pay out more to maintain reputations.

Tax Issues

Economists are divided on the effects of taxes on the valuation of dividends (Poterba and Summers 1985). On the so-called traditional view, heavy taxation of dividends at both the 
corporate and personal levels -- at least in the United States -- is a strong deterrent to paying out dividends rather than retaining the earnings. There are two important objections to this view. One objection, raised by Miller and Scholes (1978), states that investors have access to a variety of dividend tax avoidance strategies that allow them to effectively escape dividend taxes. This objection does not closely correspond to what investors actually do (Feenberg 1981). Another objection, the so-called new view of dividends and taxes (e.g., King 1977, Auerbach 1979), argues that cash has to be paid out as dividends sooner or later, and therefore paying it earlier in the form of current dividends imposes no greater a tax burden on shareholders than does the delay. On this theory, taxes do not deter dividend payments. Some recent research, such as Harris et al. (1997), supports this new view. In our empirical work, we include a measure of the tax disadvantage of dividends based on Poterba and Summers $(1984,1985)$ to assess the effect of taxes on dividend policies. Appendix 1 summarizes in detail our treatment of the tax effects of dividends, and also presents the data on taxes that we use in the empirical work.

III. Data.

Our sample is based on the March 1996 edition of the WorldScope Database, which presents information on the (typically) largest listed firms in 46 countries. There are 13,698 firms in the original data base. Since accounting data are often reported with a delay, our analysis uses 1994 data. Table 1, Panel A summarizes the construction of the sample. From the original universe, we eliminate firms trading in socialist countries and in Luxembourg; firms listed in countries with mandatory dividend policies (i.e., legal requirements that a certain fraction of net income is paid out as dividends); financial firms; firms completely or partially 
owned by the government (as best we can identify them); firms without consolidated balance sheets in 1989, 1994, or both; firms with negative net income or negative cash flow in 1994; firms with missing dividend data in 1994 or missing sales, net income, or cash flow data in 1994 or 1989; firms whose dividends exceed sales; and finally, 3 firms that do not appear to be publicly traded. This leaves us with the basic sample of 4,103 firms from only 33 countries for which we can compute dividend payout ratios in 1994 and sales growth rates from 1989 to 1994. Panel B shows how we get from 46 to 33 countries.

We note in particular the exclusion of countries with mandatory dividend rules, namely Brazil, Chile, Colombia, Greece, and Venezuela. The mandatory dividend countries share extremely weak legal protection of minority investors. The fact that, in such environments, regulators choose to force companies to pay dividends is in itself some evidence in favor of the importance of agency considerations, since the most plausible reason for a mandatory dividend policy is to assure outside investors that they would not be expropriated entirely, and thus to encourage participation in the equity markets by such investors (La Porta et al. 1998).

Table 2 summarizes the construction of the variables. We use two rough proxies for protection of minority shareholders. The first is a dummy equal to one if a country's company law or commercial code is of civil origin, and zero for common law origin. Because we have data on fewer countries, we do not distinguish between French, German, and Scandinavian civil law origins in this paper, as we did in La Porta et al. $(1997,1998)$. Shareholder protection scores across civil law families are more similar than they are to common law scores. The second measure of investor protection, the low investor protection dummy, is equal to one if the index of anti-director rights is below the sample median. We rely on the refined and extended index on 
anti-director rights from La Porta et al. (1998), which reflects such aspects of minority rights as the ease of voting for directors, the possibility of electing directors through a cumulative voting mechanism, the existence of a grievance mechanism for oppressed minority shareholders, such as a class action lawsuit, the percentage of votes needed to call an extraordinary shareholder meeting, and the existence of pre-emptive rights. La Porta et al. (1997) find that the anti-director rights score is a good predictor of stock market development across countries.

Since we are dealing with accounting data in countries with different accounting standards, we compute several measures of the dividend payout ratio. The numerator in these ratios is the total cash dividend paid to common and preferred shareholders. The denominators are cash flow, earnings, and sales. The dividend-to-cash-flow ratio has a natural economic interpretation, since it is the ratio of cash distributed in a period to cash generated. The dividendto-earnings ratio is the most commonly used measure of dividend payouts. The two ratios have several problems, however. First, both of them may depend on a country's accounting conventions, and hence may not be exactly comparable across countries. Second, these ratios have the potential problem of being easily manipulated by accounting tricks. Third, and perhaps most important, diversion of resources may occur before earnings or cash flows are reported, in which case these two ratios overestimate the share of true earnings that is paid out as dividends. Fortunately, if diversion is greater in countries with poor shareholder protection, this problem biases the results toward finding higher payouts in these countries than is really the case. Our results of lower measured payouts in countries with poor investor protection reported below would thus be even stronger if true earnings and cash flows were higher than reported. Still, as an additional guard against these problems, we also present the dividends-to-sales ratio, since 
sales are less dependent on accounting conventions, are harder to manipulate or smooth though accounting practices, and are less subject to theft. Sales should be viewed just as a deflator; the economic interpretation of this ratio is not transparent.

For each firm, we also compute its annual real sales growth rate over the five year period from 1989 to 1984 . We are interested in the expected growth rate rather than the past growth rate, but use the past growth rate as a rough proxy for expected future growth. We use sales rather than earnings growth to avoid dealing with the volatility and manipulability of earnings.

For our dividend payout ratios and the sales growth rate, we also compute industry adjusted measures. For each company in a given industry, we make this adjustment relative to the world-wide rather than country-wide measure for that industry (i.e., we take out world-wide industry effects rather than country-industry effects). Consider the computation of the industryadjusted growth in sales, for example. We first find for each industry in each country the median real growth rate of sales in that industry in that country. We then take the median of country medians, thus obtaining the world-wide median growth in real sales in the industry. Our measure of industry-adjusted growth in sales for a company is the difference between that company's sales growth, and the world median sales growth in its industry. The idea is that different industries might be at different stages of maturity and growth that determine their dividend policies.

Table 3 summarizes the data by presenting the number of observations we have for each country as well as country medians of several variables. Of the firms in our sample, a little over a quarter $(1,135)$ are from civil law countries and a little over three quarters $(2,968)$ are from common law countries. Over half the firms in the sample come from the United States and the 
United Kingdom. Both of these countries have a large number of listed firms; WorldScope coverage and the quality of data are also better for richer countries. India, for example, has 5,398 listed firms in 1995, but only one of them makes it into the sample.

The second column of Table 3 illustrates the finding of our earlier work, namely that common law countries on average have stronger shareholder protection, as illustrated by the median of the low shareholder protection dummy, than civil law countries do. The z-statistic on the difference in the median civil law and common law shareholder protection is 3.97.

The next three columns present country medians of our three dividend payout ratios. The median of country medians dividend-to-earnings ratio, the most common payout metric used in the United States, is about 30 percent, confirming that a substantial share of earnings is paid out as dividends ${ }^{5}$. Paying dividends is indeed what large firms just about everywhere do, and there is a dividend puzzle to be explained. Table 3 also reveals that, for all measures, common law countries have higher payouts than civil law countries, and for two out of three the difference is statistically significant at the 5 percent level. We discuss this result in more detail below.

The next column shows that the median of country medians real growth rate of sales in the sample is 4.13 percent. The cross-country correlation between medians of sales growth rates in our sample and real GNP growth rates is .55, indicating that our sales growth measures are typical for company growth rates in various countries. At the median of country medians, firms in civil law countries grow one percent faster than firms in common law countries.

A final point on Table 3 is that, in most countries, the difference between the tax

${ }^{5}$ Note that, in the calculation of this measure, the US and the UK do not receive any more weight than any other country. 
treatment of dividends and retained earnings is small. The United States, with its significant tax advantage of retained earnings, is relatively extreme.

IV. Results.

Simple Statistics

We present the results in two steps. In Tables 4 and 5, we present some basic statistics from our sample of firms that bear on the hypotheses described in Section II. In Tables 6 and 7 we present the regressions that control for tax and industry effects.

In Tables 4 and 5, we present medians of country medians (moms) of dividend payout ratios for various groups of firms, and in particular distinguish between rapidly and slowly growing firms. To have reasonably robust statistics, we use a narrower sample in these tables than we do in Table 3. Specifically, we only consider countries where we have at least five firms with sales growth above the world median sales growth of 4.1 percent, and five firms with sales growth below the world median. This restriction leaves us with 24 countries, and eliminates countries with very few firms from the analysis. In the regressions, we go back to the broader sample.

In Table 4, we examine whether firms in civil and common law countries have different dividend payout policies. To begin, we compute the mom for the three dividend payout ratios for the civil and common law families separately (the same measures, for a broader sample, were presented in Table 3). The results of this calculation are presented in the first column of Table 4 . For all three ratios, common law countries have a sharply higher dividend payout ratio than civil law countries do. The mom dividend to cash flow ratio is 17 percent for common law countries, 
and only 10.6 percent for civil law countries. The mom dividend to earnings ratios are 36.3 percent for common law countries, and 27.7 percent for civil law countries. The mom dividend to sales ratio is 2 percent for common law countries and .8 percent for civil law countries. For all three variables, these estimates are very close to those for the broader sample in Table 3. Panel D of Table 4 shows that, for two out of the three measures of dividend payouts, the difference between the common law mom payout and the civil law mom payout is statistically significant.

The results in the first column of Table 4 are central to this paper. Recall that common law countries generally have stronger minority shareholder protection than civil law countries. The fact that common law countries also have higher dividend payouts supports the outcome agency model of dividends, according to which better shareholder protection leads to higher dividend payouts. In contrast, the result is inconsistent with the basic prediction of the substitute agency model of dividends. More generally, the fact that dividend payouts are so different in environments with different shareholder protection suggests that agency considerations are likely to be central to the explanation of why firms pay dividends.

The additional results in Table 4 address the relationship between dividend payout rates and growth rates across legal regimes. For each country with enough observations (see above), we separately compute the median payout ratio for firms with above and firms with below the world median sales growth rate. Within each origin, we then compute the mom payout across countries for rapidly and slowly growing firms separately. The results are presented in the last two columns of Table 4, and again are consistent across all three measures of dividend payouts. In common law countries, payout ratios are strictly higher for slowly growing firms than for rapidly growing firms. In this family, the mom dividend to cash flow ratio is 15.2 percent for 
rapidly growing firms and 22.9 percent for slowly growing firms; the mom dividend to earnings ratio is 28 percent for rapidly growing firms and 41 percent for slowly growing firms; and the mom dividend to sales ratio is 1.8 percent for rapidly growing firms and 2.9 percent for slowly growing firms. These differences between mature and growth firms in common law countries are statistically significant (see Panel D). These results are broadly consistent with the predictions of the outcome agency model of dividends, according to which well-protected minority shareholders are willing to delay dividends in firms with good growth prospects.

In the civil law family, in contrast, rapidly growing firms appear, if anything, to pay higher dividends. In this family, the mom dividend to cash flow ratio is 10.9 percent for rapidly and 9.2 percent for slowly growing firms; the mom dividend to earnings ratio is 30.3 percent for rapidly and 21.3 percent for slowly growing firms; and finally the mom dividend to sales ratio .9 percent for rapidly and .8 percent for slowly growing firms. The positive association between dividend payouts and growth rates in civil law countries is consistent with the dividends as substitutes theory applying to these countries. However, as Panel D shows, these payout differences between mature and growth firms in civil law countries are not statistically significant, and hence we should not read too much into this finding.

Table 5 presents calculations similar to those in Table 4, except that now countries are sorted by whether the low shareholder protection dummy is equal to zero or one. As in Table 4, we use the narrow sample of countries. The results are similar to those in Table 4, and we summarize them only briefly. First, on all measures of dividend payouts, countries with better shareholder protection have higher dividend payout ratios than do countries with worse protection. Second, again on all measures of dividend payouts, within countries with good 
shareholder protection, high growth firms have lower dividend payouts than low growth firms. The differences are statistically significant at the 5 percent level in two cases, and at the 10 percent level in the third. Finally, on all measures of dividend payouts, within countries with low shareholder protection, high growth firms have higher dividend payouts than low growth firms. These differences are not statistically significant, however.

The preliminary results are consistent with the outcome agency model. However, the findings may be driven by some heterogeneity of countries correlated with legal origin or investor protection. Accordingly, we next move to a regression analysis that attempts to control for the differences in tax regimes and in industrial composition in different countries.

\section{Regressions}

Table 6 presents the results of regressions across 4,103 firms in 33 countries around the world. We use the broader sample described in Table 3. We employ a random effects specification that explicitly accounts for the cross-correlation between error terms for firms in the same country. We control for the tax advantage of dividends, which is specific to each country, but not for industry effects until Table 7 . We report results for all three measures of the dividend payout ratio. We use dummies to proxy for the quality of legal protection of investors. For each payout variable, we present one regression that distinguishes between common and civil law countries, and one regression that distinguishes between low and high investor protection. As a measure of sales growth in the regressions, we use the decile rank of the actual average annual sales growth rate for each firm, GS_decile, where the distribution of growth rates is taken over all the firms in the sample. Using deciles gives us a less widely-spread variable. We also 
include an interaction between GS_decile and the legal origin or the low investor protection dummy.

The tax variable enters with the positive sign in all specifications, but is only statistically significant in the dividend-to-sales ratio regressions. The interpretation of this result is highly ambiguous. The positive coefficients can be interpreted as some support for the traditional view, under which taxes discourage the payment of dividends. The insignificance of these coefficients, however, may be interpreted as evidence in favor of the "new view," under which tax payments are already capitalized in the value of the firm and therefore do not influence dividend policy. Last, the evidence may mean that our computations do not adequately address the nuances of each country's tax treatment of dividends.

The civil law dummy enters with a negative and significant at the $1 \%$ level coefficient in all three regressions where it is included. Using the dividend to cash flow ratio, common law countries have a 13.3 percentage points higher payout, other things equal. The coefficient on GS_decile is negative and also significant at the $1 \%$ level, and implies that, for common law countries, moving from the bottom to the top decile of sales growth rate is associated with a 7.6 percentage point lower dividend to cash flow ratio. That is, in common law countries, higher growth firms pay moderately lower dividends. At the same time, the coefficient on the interaction between GS_decile and the civil law dummy is highly statistically significant and of roughly the same magnitude as that on GS_decile in all three regressions. This implies that, other things equal, there is no relationship between sales growth and dividend payouts in civil law countries. The results using the civil law dummy are consistent with the medians in Table 4 , and support the outcome agency model of dividends. 
Similar results obtain using the low shareholder protection dummy. The coefficient on that dummy is negative and significant at the $1 \%$ level in all three regressions. The coefficient on GS_decile as before is negative and significant, implying that, in countries with good shareholder protection, faster growing firms pay lower dividends. The coefficient on the interaction between GS_decile and the low shareholder protection dummy is positive and of about the same magnitude, indicating that the relationship between growth and payouts does not hold in countries with poor shareholder protection. These results as well suggest that dividends are an outcome of the pressure on the insiders to pay out profits.

In Table 7, we use industry adjusted growth in sales and industry adjusted dividends to control for industry effects, and otherwise estimate the same equations as in Table 6 (the details of the adjustment are described in Table 2 and at the top of Table 7). The industry adjustment does not change the thrust of our results. Countries from the common law family, as well as countries with good shareholder protection, pay higher industry-adjusted dividends, and moreover, in these countries, faster growing firms pay lower dividends, other things equal.

As a final point in this section, we briefly address a possibly important objection to our analysis, which states that perhaps the evidence of lower payouts in civil law (or poor shareholder protection) countries simply reflects greater reliance on debt finance in those countries. There are several problems with this objection. First, as an empirical matter, we use the ratios of dividends to cash flow and to earnings, so the denominators already take out interest payments. Even if firms in civil law countries rely on debt to a greater extent, they should not necessarily pay out less of their net-of-interest income. The fact that poor shareholder protection is associated with lower payouts is thus not obviously explained by this objection. Second, at a 
broader level, it is not generally the case that firms in civil law countries have greater reliance on debt finance. Indeed, many of these countries, particularly French civil law countries, have poor legal protections of both shareholders and creditors, and hence have both smaller debt and smaller equity markets (La Porta et al. 1997). The idea that countries with poorly developed stock markets necessarily, or even on average, have better developed lending mechanisms is simply a myth. Last, we have actually tested the validity of this objection by including a country-specific measure of debt finance from La Porta et al. (1997), namely the ratio of aggregate private debt to GNP, in the regressions in Table 6 and 7 . The coefficients on the debt variable are positive, though generally insignificant, while the magnitudes and the statistical significance of shareholder protection coefficients remain largely unaffected. This finding is inconsistent with the argument that poor shareholder protection is associated with dividend payouts because of substitution of financing into debt. For all these reasons, we continue to take our evidence as supportive of the outcome agency model of dividends.

\section{Conclusion.}

This paper uses a sample of firms from 33 countries around the world to shed light on dividend policies of large corporations. We take advantage of different legal protection of minority shareholders across these countries to compare dividend policies of companies whose minority shareholders face different risks of expropriation of their wealth by corporate insiders. We use this cross-sectional variation to examine the agency approach to dividend policy.

We distinguish two alternative agency models of dividends. On the first model, dividends are an outcome of effective legal protection of shareholders, which enables minority 
shareholders to extract dividend payments from corporate insiders. On the second, dividends are a substitute for effective legal protection, which enables firms in unprotective legal environments to establish reputations for good treatment of investors through dividend policies.

Our data suggest that the agency approach is highly relevant to an understanding of corporate dividend policies around the world. More precisely, we find consistent support for the outcome agency theory of dividends. Firms operating in countries with better protections of minority shareholders pay higher dividends. Moreover, in these countries, faster growing firms pay lower dividends than slower growing firms, consistent with the idea that legally protected shareholders are willing to wait for their dividends when investment opportunities are good. On the other hand, poorly protected shareholders seem to take whatever dividends they can get, regardless of investment opportunities. This apparent misallocation of investment is presumably part of the agency cost of poor legal protection.

In our analysis, we find no conclusive evidence on the effect of taxes on dividend policies. Nor can we use our data to assess the relevance of dividend signalling. In fact, our results are consistent with the idea that, on the margin, dividend policies of firms may convey information to some investors. Despite the possible relevence of alternative theories, firms appear to pay out cash to investors because the opportunities to steal or misinvest it are in part limited by law, and because minority shareholders have enough power to extract it. In this respect, the quality of legal protection of investors is as important for dividend policies as it is for other key corporate decisions. 


\section{References.}

Aharony, Joseph and Itzhak Swary, 1980, Quarterly dividend and earnings announcements and stockholder returns: An empirical analysis, Journal of Finance 35, 1-12.

Allen, Franklin and Roni Michaely, 1997, Dividend policy, in Robert Jarrow, Vojislav Maskimovic, and William Ziemba, eds., North-Holland Handbooks in Operations Research and Management Science: Finance, Amsterdam: North-Holland.

Ambarish, Ramasastry, Kose John, and Joseph Williams, 1987, Efficient Signalling with Dividends and Investments, Journal of Finance 42, 321-343.

Asquith, Paul and David Mullins, 1983, The impact of initiating dividend payments on shareholders' wealth, Journal of Business 56, 77-96.

Auerbach, Alan, 1979, Wealth maximization and the cost of capital, Quarterly Journal of Economics 93, 433-446.

Baumol, William, 1959, Business Behavior, Value and Growth (Macmillan, New York).

Benartzi, Shlomo, Roni Michaely, and Richard Thaler, 1997, Do changes in dividends signal the future or the past?, Journal of Finance 52, 1007-1034.

Berle, Adolf and Gardiner Means, 1932, The Modern Corporation and Private Property (Macmillan, New York),

Bhattacharya, Sudipto, 1979, Imperfect information, dividend policy, and the "bird-in-hand" phallacy, Bell Journal of Economics 10, 259-270.

Black, Fischer, 1976, The dividend puzzle, Journal of Portfolio Management 2, 5-8.

De Angelo, Harry, Linda De Angelo and Douglas Skinner, 1996, Reversal of fortune: Dividend policy and the disappearance of sustained earnings growth, Journal of Financial 
Economics 40, 341-371.

Dewenter, Kathryn L. and Warther, Vincent A., 1998, Dividends, Asymetric Information, and Agency Conflicts: Evidence from a comparison of the dividend policies of Japanese and U.S. Firms, Journal of Finance 53, forthcoming.

Easterbrook, Frank, 1984, Two agency cost explanations of dividends, American Economic Review 74, 650-659.

Feenberg, Daniel, 1981, Does the investment interest limitation explain the existence of dividends?, Journal of Financial Economics 9, 265-269.

Fluck, Zsuzsanna, 1995, The optimality of debt versus outside equity, NYU Mimeo.

Fluck, Zsuzsanna, 1998, The Dynamics of the Management-Shareholder Conflict, Mimeo, NYU. Gomes, Armando, 1996, Dynamics of stock prices, manager ownership, and private benefits of control, manuscript, Harvard University.

Harris, Trevor, Glenn Hubbard, and Deen Kemsley, 1997, Are dividend taxes and tax imputation credits capitalized in share values?, manuscript, Columbia University.

Hart, Oliver and John Moore, 1994, A theory of debt based on inalienability of human capital, Quarterly Journal of Economics 109, 841-880.

Jensen, Michael, 1986, Agency cost of free cash flow, corporate finance, and takeovers, American Economic Review Papers and Proceedings 76, 323-329.

Jensen, Michael and Wiliam Meckling, 1976, Theory of the firm: managerial behavior, agency costs, and capital structure, Journal of Financial Economics 3, 305-360.

John, Kose and Joseph Williams, 1985, Dividends, dilution, and taxes: a signalling equilibrium, Journal of Finance 40, 1053-1070. 
Kang, Jun-Koo and René M. Stulz, 1996, How Different is Japanese Corporate Finance? An Investigation of the Information Conflict of New Security Issues, The Review of Financial Studies 9, 109-139.

King, Mervyn, 1977, Public policy and the corporation, London: Chapman and Hall.

La Porta, Rafael, Florencio Lopez-de-Silanes, and Andrei Shleifer, 1998, Corporate Ownership Around the World, Mimeo, Harvard University.

La Porta, Rafael, Florencio Lopez-de-Silanes, Andrei Shleifer, and Robert W. Vishny, 1997, Legal determinants of external finance, Journal of Finance 52, 1131-1150.

La Porta, Rafael, Florencio Lopez-de-Silanes, Andrei Shleifer, and Robert W. Vishny, 1998, Law and Finance, Journal of Political Economy 106, December.

Lintner, John, 1956, Distribution of income of corporations amond dividends, retained earnings, and taxes, American Economic Review 46, 97-113.

Miller, Merton and Franco Modigliani, 1961, Dividend policy, growth, and the valuation of shares, Journal of Business 34, 411-433.

Miller, Merton and Kevin Rock, 1985, Dividend policy under asymmetric information, Journal of Finance 40, 1031-1051.

Miller, Merton and Myron Scholes, 1978, Dividends and taxes, Journal of Financial Economics $6,333-364$.

Modigliani, Franco and Merton Miller, 1958, The cost of capital, corporation finance, and the theory of investment, American Economic Review 48, 261-297.

Myers, Stewart, 1996, Outside equity financing, MIT Working Paper.

Poterba, James and Lawrence Summers, 1984, New evidence that taxes affect the valuation of 
dividends, Journal of Finance 39, 1397-1415.

Poterba, James and Lawrence Summers, 1985, The economic effects of dividend taxation, in Edward Altman and Marti Subramanyam, eds., Recent Advances in Corporate Finance, Homewood, IL.: Richard D. Irwin Publishers.

Rajan, Raghuram and Luigi Zingales, 1995, What do we know about capital structure?: Some evidence from the international data, Journal of Finance 50, 1421-1460.

Shleifer, Andrei and Robert W. Vishny, 1997, A survey of corporate governance, Journal of Finance 52, 737-783. 


\section{Table 1}

\section{Panel A: Construction of the Sample}

\section{3,69 WorldScope Sample (3/96 version)}

-56 Firms listed in stock exchanges of former socialist countries

-12 Firms listed in Luxembourg's stock exchange

-323 Firms listed in stock exchanges of countries with mandatory dividend policies

-2,836 Financial firms (primary and/or secondary SIC between 6,000 and 6,999)

-335 State owned enterprises (direct and/or indirect government ownership)

$-1,296$ Unconsolidated balance sheets in 1989, 1994, or both

-3,878 Missing sales in 1989 and/or dividends, cash flows, net income or sales in 1994

-832 Negative net income before extraordinary items in 1994

-11 Negative cash-flow in 1994

-13 Dividends > Sales

-3 Not publicly traded (ie, cooperatives and privately owned firms)

4,103 Basic Sample

\section{Panel B: Countries in the Sample}

\begin{tabular}{r|l}
\hline 46 & Countries in WorldScope \\
-3 & Socialist/Former Socialist (China, Poland, Hungary) \\
-1 & Luxembourg \\
-5 & Mandatory Dividend Countries (Brazil, Chile, Colombia, Greece, Venezuela) \\
-4 & Countries that do not meet data requirements (Israel, Pakistan, Peru, Sri Lanka) \\
\hline 33 & Countries in the Sample \\
\hline
\end{tabular}




\section{Table 2 : The Variables}

This table describes the variables collected for the thirty three countries included in our study. The first column gives the name of the variable. The second column describes the variable and provides the sources from which the variable was collected.

\begin{tabular}{ll}
\hline Variable & \multicolumn{1}{c}{ Description } \\
\hline Common Law & $\begin{array}{l}\text { Equals one if the origin of the Company Law or Commercial Code of the country is } \\
\text { the English Common Law and zero otherwise. Source: Foreign Law Encyclopedia } \\
\text { and Commercial Laws of the World }\end{array}$
\end{tabular}

Civil Law

Low Protection

High Protection

Dividend-to-Cash-flow

IA_Dividend-to-Cash-flow

Dividend-to-Earnings
Equals one if the Company Law or Commercial Code of the country originates in Roman Law and 0 otherwise. Source: Foreign Law Encyclopedia and Commercial Laws of the World.

Equals one if the index of antidirectors rights is smaller or equal than three (the sample median). The index of antidirectors rights is formed by adding one when: (1) the country allows shareholders to mail their proxy vote; (2) shareholders are not required to deposit their shares prior to the General Shareholders' Meeting; (3) cumulative voting or proportional representation of minorities on the board of directors is allowed; (4) an oppressed minorities mechanism is in place; (5) the minimum percentage of share capital that entitles a shareholder to call for an Extraordinary Shareholders' Meeting is less than or equal to ten percent (the sample median); (6) or when shareholders have preemptive rights that can only be waved by a shareholders meeting. The range for the index is from zero to six. Source: La Porta et al. (1996, revised).

Equals one if Low Protection equals zero. Source: La Porta et al. (1996, revised).

Dividends as a percentage of cash flow in fiscal year 1994. Dividend are defined as total cash dividend paid to common and preferred shareholders. Cash flow is measured as the difference between total funds from operations and non-cash items from discontinued operations. Source: WorldScope Database.

Industry-adjusted dividend-to-cash-flow ratio for a firm. To calculate IA_Dividend-to-Cash-flow, we first find for each industry in each country the median of the Dividend-to-Cash-flow ratio (C_D/CF). Then for each industry in the sample we define the world median as the median of C_D/CF across countries. Finally, we calculate IA_Dividend-to-Cash-flow as the difference between the firm's Dividend-to-Cash-flow and the world median Dividend-to-Cash-flow for the firm's industry. We rely on a firm's primary SIC to define the following seven broad industries: (1) agriculture; (2) mining; (3) construction; (4) light manufacturing; (5) heavy manufacturing; (6) communications and transportation; and (7) services. Source: WorldScope Database.

Dividends as a percentage of Earnings in fiscal year 1994. Dividend are defined as total cash dividends paid to common and preferred shareholders. Earnings are measured after taxes and interest but before extraordinary items. Source: WorldScope Database. 


\begin{tabular}{ll}
\hline Variable & \multicolumn{1}{c}{ Description } \\
\hline IA_Dividend-to-Earnings & Industry-adjusted dividend-to-earnings ratio for a firm. To calculate \\
& IA_Dividend-to-Earnings, we first find for each industry in each country the \\
& median of the Dividend-to-Earnings ratio (C_D/E). Then for each industry in the \\
& sample we define the world median as the median of C_D/E across countries. \\
& Finally, we calculate IA_Dividend-to-Earnings as the difference between the firm's \\
& Dividend-to-Earnings and the world median Dividend-to-Earnings for the firm's \\
& industry. We rely on a firm's primary SIC to define the following seven broad \\
& industries: (1) agriculture; (2) mining; (3) construction; (4) light manufacturing; (5) \\
& heavy manufacturing; (6) communications and transportation; and (7) services. \\
& Source: WorldScope Database. \\
& Dividends as a percentage of sales in fiscal year 1994. Dividends are defined as \\
& total cash dividends paid to common and preferred shareholders. Sales are net sales. \\
& Source: WorldScope Database. \\
& Industry-adjusted dividend-to-sales ratio for a firm. To calculate \\
Dividend-to-Sales & IA_Dividend-to-Sales, we first find for each industry in each country the median of \\
& the Dividend-to-Sales ratio (C_D/S). Then for each industry in the sample we define \\
& the world median as the median of C_D/S across countries. Finally, we calculate \\
IA_Dividend-to-Sales & IA_Dividend-to-Sales as the difference between the firm's Dividend-to-Sales and \\
the world median Dividend-to-Sales for the firm's industry. We rely on a firm's \\
primary SIC to define the following seven broad industries: (1) agriculture; (2) \\
mining; (3) construction; (4) light manufacturing; (5) heavy manufacturing; (6) \\
communications and transportation; and (7) services. Source: WorldScope \\
Database..
\end{tabular}

GS

GS_Decile

IA_GS

IA_GS_Decile

Average annual percentage growth in (net) sales over the period 1989-1994. Sales are expressed in real (US\$) dollars using the GNP deflator. Source: WorldScope Database and International Financial Statistics (May 1996).

Rank decile for GS. Ranges from 1 to 10.

Average annual Industry-adjusted growth in (net) sales over the period 1989-1994. To calculate IA_GS, we first find for each industry in each country the median of the GS (C_GS). Then for each industry in the sample we define the world median as the median of C_GS across countries. Finally, we calculate IA_GS as the difference between the firm's GS and the world median GS for the firm's industry. We rely on a firm's primary SIC to define the following seven broad industries: (1) agriculture; (2) mining; (3) construction; (4) light manufacturing; (5) heavy manufacturing; (6) communications and transportation; and (7) services. Source: WorldScope Database.

Rank decile for IA_GS. Ranges from 1 to 10.

Dividends Tax Adv. The ratio of the value, to an outside investor, of US\$1 distributed as dividend income to the value of US $\$ 1$ received in the form of capital gains when kept inside the firm as retained earnings. The computation of this ratio is described in Appendix 1. Sources: Ernst and Young (1994), Price Waterhouse (1995), and OECD (1991). 
Table 3: The Data

Panel A classifies countries by legal origin and presents medians by country. Definitions for each of the variables can be found in Table 2. Panel B reports tests of medians for civil versus common legal origin.

\begin{tabular}{|c|c|c|c|c|c|c|c|}
\hline Country & $\mathrm{N}$ & $\begin{array}{c}\text { Low } \\
\text { Protection }\end{array}$ & $\begin{array}{c}\text { Div/CF } \\
(\%)\end{array}$ & $\begin{array}{c}\text { Div/Earn } \\
(\%)\end{array}$ & $\begin{array}{c}\text { Div/Sales } \\
(\%)\end{array}$ & $\begin{array}{c}\text { GS } \\
\text { (Annual) }\end{array}$ & $\begin{array}{c}\text { Div Tax } \\
\text { Adv }\end{array}$ \\
\hline \multicolumn{8}{|c|}{ Panel A: Medians } \\
\hline Argentina & 3 & 0 & 12.65 & 27.36 & 4.32 & 14.32 & 1.00 \\
\hline Austria & 9 & 1 & 5.85 & 24.83 & 0.77 & 13.31 & 0.78 \\
\hline Belgium & 33 & 1 & 11.77 & 39.38 & 1.09 & 3.78 & 0.74 \\
\hline Denmark & 75 & 1 & 6.55 & 17.27 & 0.71 & 4.32 & 0.67 \\
\hline Finland & 39 & 1 & 8.08 & 21.27 & 0.77 & -2.14 & 1.07 \\
\hline France & 246 & 1 & 9.46 & 23.55 & 0.63 & 4.54 & 0.64 \\
\hline Germany & 146 & 1 & 12.70 & 42.86 & 0.83 & 5.88 & 0.86 \\
\hline Indonesia & 1 & 1 & 8.72 & 25.11 & 0.77 & 32.62 & 0.76 \\
\hline Italy & 58 & 1 & 9.74 & 21.83 & 0.92 & -1.38 & 0.77 \\
\hline Japan & 149 & 0 & 13.03 & 52.88 & 0.72 & 6.19 & 0.70 \\
\hline S. Korea & 2 & 1 & 7.33 & 18.49 & 0.66 & 5.29 & 0.79 \\
\hline Mexico & 14 & 1 & 19.47 & 46.44 & 3.59 & 8.02 & 1.00 \\
\hline Netherlands & 96 & 1 & 11.29 & 30.02 & 0.74 & 4.13 & 0.40 \\
\hline Norway & 50 & 0 & 10.74 & 23.91 & 0.98 & 4.43 & 1.08 \\
\hline Philippines & 4 & 1 & 6.72 & 10.47 & 2.45 & -7.29 & 1.05 \\
\hline Portugal & 17 & 1 & 0.64 & 38.01 & 0.64 & 8.20 & 0.98 \\
\hline Spain & 33 & 0 & 15.77 & 30.45 & 1.04 & 1.32 & 0.72 \\
\hline Sweden & 81 & 1 & 5.59 & 18.33 & 0.78 & -0.63 & 1.03 \\
\hline Switzerland & 70 & 1 & 10.38 & 25.30 & 0.98 & 3.73 & 0.56 \\
\hline Taiwan & 3 & 1 & 48.97 & 68.89 & 11.54 & 1.62 & 0.60 \\
\hline Turkey & 6 & 1 & 8.61 & 22.64 & 2.08 & 0.16 & 0.90 \\
\hline Civil Law Median & 33 & 1 & 9.74 & 25.11 & 0.83 & 4.32 & 0.78 \\
\hline Australia & 103 & 0 & 22.83 & 42.82 & 2.22 & 2.21 & 0.90 \\
\hline Canada & 236 & 0 & 8.00 & 19.78 & 0.78 & -0.62 & 0.89 \\
\hline Hong Kong & 40 & 0 & 35.43 & 45.93 & 7.51 & 7.94 & 1.00 \\
\hline India & 1 & 0 & 25.69 & 49.34 & 1.55 & -0.09 & 0.59 \\
\hline Ireland & 16 & 0 & 17.39 & 27.28 & 0.96 & 9.96 & 0.77 \\
\hline Malaysia & 41 & 0 & 15.29 & 37.93 & 3.12 & 16.31 & 0.68 \\
\hline New Zealand & 17 & 0 & 19.16 & 35.60 & 2.26 & 3.11 & 1.00 \\
\hline Singapore & 27 & 0 & 22.28 & 41.04 & 2.14 & 11.02 & 0.96 \\
\hline South Africa & 90 & 0 & 16.16 & 35.62 & 1.90 & 3.47 & 0.85 \\
\hline Thailand & 10 & 1 & 32.83 & 52.56 & 3.35 & 17.73 & 0.90 \\
\hline United Kingdom & 799 & 0 & 16.67 & 36.91 & 1.89 & 2.44 & 0.83 \\
\hline United States & 1,588 & 0 & 11.38 & 22.11 & 0.95 & 3.15 & 0.58 \\
\hline Common Law Median & 40 & $\mathbf{0}$ & 18.28 & 37.42 & 2.02 & 3.31 & 0.87 \\
\hline Sample Median & 39 & 1 & 11.77 & 30.02 & 0.98 & 4.13 & 0.83 \\
\hline \multicolumn{8}{|c|}{ Panel B: Test of Medians (z-statistic) } \\
\hline Civil vs Common Law & & $3.97^{\mathrm{a}}$ & $-3.29^{\mathrm{a}}$ & $-1.72^{\mathrm{c}}$ & $-2.36^{\mathrm{b}}$ & -0.34 & -0.09 \\
\hline
\end{tabular}

$a=$ Significant at $1 \%$ level; $b=$ Significant at $5 \%$ level; $c=$ Significant at $10 \%$ level. 


\section{Table 4}

This table classifies firms based on both the legal origin of the country in which they are incorporated and on their growth in sales (GS) relative to the world median growth in sales. Countries are required to have at least five valid observations (firms) with growth in sales below the world median and five observations with growth in sales above the world median. The number of countries in the resulting sample is twenty four (fourteen civil law and ten common law countries). To compute the world median growth in sales we calculate the median growth in sales for each country and then we take medians again but now over the twenty four resulting country-observations. For each classification, the table reports the median value of the country-medians for the following three ratios: (1) Dividend-to-Cash-flow in Panel A; (2) Dividend-to-Earnings in Panel B; and (3) Dividend-to-Sales in Panel C. Finally, Panel D reports Z statistics for tests of difference in medians.

\begin{tabular}{|c|c|c|c|}
\hline & & "Growth" & "Mature" \\
\hline Legal Origin & All & GS $>$ World Median GS & GS $<$ World Median GS \\
\hline & \multicolumn{3}{|c|}{ Panel A: Dividend-to-Cash-Flow } \\
\hline Civil Law & 10.56 & 10.89 & 9.20 \\
\hline \multirow[t]{2}{*}{ Common Law } & 17.03 & 15.17 & 22.87 \\
\hline & \multicolumn{3}{|c|}{ Panel B: Dividend-to-Earnings } \\
\hline Civil Law & 27.66 & 30.35 & 21.27 \\
\hline \multirow[t]{2}{*}{ Common Law } & 36.27 & 27.95 & 40.88 \\
\hline & \multicolumn{3}{|c|}{ Panel C: Dividend-to-Sales } \\
\hline Civil Law & 0.80 & 0.89 & 0.77 \\
\hline \multirow[t]{3}{*}{ Common Law } & 2.02 & 1.77 & 2.91 \\
\hline & \multicolumn{3}{|c|}{ Panel D: Z-Stat for differences in Medians } \\
\hline & Div/CF & Div/Earn & Div/Sales \\
\hline Civil vs Common Law & $-2.81^{\mathrm{a}}$ & -0.76 & $-2.75^{\mathrm{a}}$ \\
\hline Civil Law: Mature vs Growth & -0.92 & -0.87 & -0.92 \\
\hline Common Law: Mature vs Growth & $2.34^{\mathrm{b}}$ & $2.42^{\mathrm{b}}$ & $1.74^{\mathrm{c}}$ \\
\hline
\end{tabular}

$a=$ Significant at $1 \%$ level; $b=$ Significant at $5 \%$ level; $c=$ Significant at $10 \%$ level. 


\section{Table 5}

This table classifies firms based both on the level of investor protection of the country in which they are incorporated (Low or High Protection) and on their growth in sales (GS) relative to the world median growth in sales. Countries included are required to have at least five valid observations (firms) with growth in sales below the world median and five observations with growth in sales above the world median. The number of countries in the resulting sample is twenty four (eleven with Low Protection equal to one). To compute the world median growth in sales we calculate the median growth in sales for each country and then we take medians again but now over the twenty four resulting country-observations. For each classification, the table reports the median value of the country-medians for the following three ratios: (1) Dividend-to-Cash-flow in Panel A; (2) Dividend-to-Earnings in Panel B; and (3) Dividendto-Sales in Panel C. Finally, Panel D reports Z statistics for tests of difference in medians.

\begin{tabular}{|c|c|c|c|}
\hline & & "Growth" & "Mature" \\
\hline Investor Protection & All & GS $>$ World Median GS & GS $<$ World Median GS \\
\hline & \multicolumn{3}{|c|}{ Panel A: Dividend-to-Cash-Flow } \\
\hline Low Protection & 9.74 & 10.86 & 8.74 \\
\hline \multirow[t]{2}{*}{ High Protection } & 16.16 & 14.51 & 18.93 \\
\hline & \multicolumn{3}{|c|}{ Panel B: Dividend-to-Earnings } \\
\hline Low Protection & 25.30 & 31.31 & 21.24 \\
\hline \multirow[t]{2}{*}{ High Protection } & 35.62 & 29.05 & 39.69 \\
\hline & \multicolumn{3}{|c|}{ Panel C: Dividend-to-Sales } \\
\hline Low Protection & 0.78 & 0.88 & 0.76 \\
\hline \multirow[t]{3}{*}{ High Protection } & 1.89 & 1.53 & 2.24 \\
\hline & \multicolumn{3}{|c|}{ Panel D: Z-Stat for differences in Medians } \\
\hline & $\mathrm{Div} / \mathrm{CF}$ & Div/Earn & Div/Sales \\
\hline Low vs High Protection & $-2.87^{\mathrm{a}}$ & -1.13 & $-2.40^{\mathrm{b}}$ \\
\hline Low-Protection: Mature vs Growth & -1.15 & -1.08 & -1.54 \\
\hline High-Protection: Mature vs Growth & $2.38^{\mathrm{b}}$ & $2.23^{\mathrm{b}}$ & $1.67^{\mathrm{c}}$ \\
\hline
\end{tabular}

$a=$ Significant at $1 \%$ level; $b=$ Significant at $5 \%$ level; $c=$ Significant at $10 \%$ level. 


\section{Table 6}

Regressions with country random effects for the cross-section of thirty three countries around the world. The dependent variables are the 1994 values of the following three ratios: (1) Dividend-to-Cash-flow; (2) Dividend-to-Earnings; and (3) Dividend-to-Sales. The independent variables are: (1) Civil Law, a dummy variable that equals one if the legal origin of the Company Law or Commercial Code of the country in which the firm is incorporated is Civil Law and zero otherwise; (2) Low Protection, a dummy variable that equals one if the Index of Antiderectors rights (described in Table 2 ) of the country in which the firm is incorporated is equal or smaller than three (the sample median) and zero otherwise; (3) GS_Decile, the decile corresponding to the firm's average annual percentage growth in sales over the period 1989 to 1994 (ranges from zero to nine); (4) the interaction between GS_Decile and Civil legal origin; (5) the interaction between GS_Decile and Low Protection; and (6) Tax Advantage of Retained Earnings (described in Table 2). Standard errors are shown in parenthesis.

\begin{tabular}{|c|c|c|c|c|c|c|}
\hline \multirow{3}{*}{$\begin{array}{l}\text { Independent Variables } \\
\text { Constant }\end{array}$} & \multicolumn{6}{|c|}{ Dependent Variables } \\
\hline & \multicolumn{2}{|c|}{ Dividend-to-Cash-flow } & \multicolumn{2}{|c|}{ Dividend-to-Earnings } & \multicolumn{2}{|c|}{ Dividend-to-Sales } \\
\hline & $\begin{array}{l}22.3730^{\mathrm{a}} \\
(3.5145)\end{array}$ & $\begin{array}{l}20.2817^{\mathrm{a}} \\
(5.0539)\end{array}$ & $\begin{array}{l}44.1156^{\mathrm{a}} \\
(8.4626)\end{array}$ & $\begin{array}{l}44.6786^{a} \\
(8.4796)\end{array}$ & $\begin{array}{c}1.8963^{\mathrm{a}} \\
(0.4005)\end{array}$ & $\begin{array}{c}1.4299 \\
(0.7812)\end{array}$ \\
\hline Civil Law & $\begin{array}{c}-13.2591^{\mathrm{a}} \\
(1.6602)\end{array}$ & & $\begin{array}{c}-16.4633^{\mathrm{a}} \\
(3.9817)\end{array}$ & & $\begin{array}{l}-2.0821^{\mathrm{a}} \\
(0.2185)\end{array}$ & \\
\hline Low Protection & & $\begin{array}{c}-10.8156^{\mathrm{a}} \\
(2.1943)\end{array}$ & & $\begin{array}{c}-18.1518^{\mathrm{a}} \\
(4.0195)\end{array}$ & & $\begin{array}{l}-1.6413^{a} \\
(0.3461)\end{array}$ \\
\hline GS_Decile & $\begin{array}{l}-0.8457^{a} \\
(0.0832)\end{array}$ & $\begin{array}{l}-0.8133^{\mathrm{a}} \\
(0.0813)\end{array}$ & $\begin{array}{l}-2.1354^{\mathrm{a}} \\
(0.1974)\end{array}$ & $\begin{array}{l}-2.0613^{\mathrm{a}} \\
(0.1927)\end{array}$ & $\begin{array}{l}-0.0859^{\mathrm{a}} \\
(0.0142)\end{array}$ & $\begin{array}{l}-0.0884^{a} \\
(0.0139)\end{array}$ \\
\hline GS_Decile * Civil & $\begin{array}{c}0.9022^{\mathrm{a}} \\
(0.1608)\end{array}$ & & $\begin{array}{c}2.3925^{\mathrm{a}} \\
(0.3816)\end{array}$ & & $\begin{array}{c}0.0962^{\mathrm{a}} \\
(0.0273)\end{array}$ & \\
\hline GS_Decile $*$ Low Protection & & $\begin{array}{c}0.8554^{\mathrm{a}} \\
(0.1695)\end{array}$ & & $\begin{array}{c}2.4253^{\mathrm{a}} \\
(0.4007)\end{array}$ & & $\begin{array}{c}0.0926^{\mathrm{a}} \\
(0.0288)\end{array}$ \\
\hline Tax Advantage of Div & $\begin{array}{c}3.2262 \\
(3.9635)\end{array}$ & $\begin{array}{c}3.5303 \\
(5.7621)\end{array}$ & $\begin{array}{c}9.5905 \\
(9.5425)\end{array}$ & $\begin{array}{c}8.9278 \\
(9.7170)\end{array}$ & $\begin{array}{c}1.8157^{\mathrm{a}} \\
(0.4556)\end{array}$ & $\begin{array}{c}2.1266^{\mathrm{b}} \\
(0.8911)\end{array}$ \\
\hline Observations & 4,103 & 4,103 & 4,102 & 4,102 & 4,103 & 4,103 \\
\hline$\chi^{2}$ & 137.79 & 109.52 & 119.38 & 118.13 & 157.59 & 61.76 \\
\hline Prob $>\chi^{2}$ & 0.0000 & 0.0000 & 0.0000 & 0.0000 & 0.0000 & 0.0000 \\
\hline
\end{tabular}

$\mathrm{a}=$ Significant at $1 \%$ level; $\mathrm{b}=$ Significant at $5 \%$ level; $\mathrm{c}=$ Significant at $10 \%$ level. 


\section{Table 7}

Regressions with country random effects for the cross-section of thirty three countries around the world. The dependent variables are the 1994 values of the following three ratios: (1) Industry-Adjusted-Dividend-to-Cash-flow; (2) IndustryAdjusted-Dividend-to-Earnings; and (3) Industry-Adjusted-Dividend-to-Sales. The independent variables are: (1) Civil Law, a dummy variable that equals one if the origin of the Company Law or Commercial Code of the country in which the firm is incorporated is Civil Law and zero otherwise; (2) Low Protection, a dummy variable that equals one if the Index of Antiderectors rights (described in Table 2) of the country in which the firm is incorporated is equal or smaller than three (the sample median) and zero otherwise; (3) IA_GS_Decile, the decile corresponding to the firm's annual average percentage industry-adjusted growth in sales over the period 1989 to 1994 (ranges from zero to nine); (4) the interaction between IA_GS_Decile and Civil legal origin; (5) the interaction between IA_GS_Decile and Low Protection; and (6) Tax Advantage of Retained Earnings (calculated as indicated in Table 2). We require at least five observations in each country/industry and report only on the industries that have the required number of observations in at least three countries. Standard errors are shown in parenthesis.

\begin{tabular}{|c|c|c|c|c|c|c|}
\hline \multirow{3}{*}{$\begin{array}{l}\text { Independent Variables } \\
\text { Constant }\end{array}$} & \multicolumn{6}{|c|}{ Dependent Variables } \\
\hline & \multicolumn{2}{|c|}{ IA_Dividend/Cash-flow } & \multicolumn{2}{|c|}{ IA_Dividend/Earnings } & \multicolumn{2}{|c|}{ IA_Dividend/Sales } \\
\hline & $\begin{array}{l}10.0288^{a} \\
(3.6114)\end{array}$ & $\begin{array}{c}8.1130^{c} \\
(4.8398)\end{array}$ & $\begin{array}{r}14.2369 \\
(9.7285)\end{array}$ & $\begin{array}{l}14.4038 \\
(9.7308)\end{array}$ & $\begin{array}{c}1.1042^{\mathrm{a}} \\
(0.4248)\end{array}$ & $\begin{array}{c}0.6490 \\
(0.8000)\end{array}$ \\
\hline Civil & $\begin{array}{r}-12.7246^{\mathrm{a}} \\
(1.6883)\end{array}$ & & $\begin{array}{c}-15.9368^{\mathrm{a}} \\
(4.4173)\end{array}$ & & $\begin{array}{l}-2.1146^{\mathrm{a}} \\
(0.2238)\end{array}$ & \\
\hline Low Protection & & $\begin{array}{c}-10.5460^{\mathrm{a}} \\
(2.1150)\end{array}$ & & $\begin{array}{c}-16.8178^{\mathrm{a}} \\
(4.2450)\end{array}$ & & $\begin{array}{l}-1.6415^{\mathrm{a}} \\
(0.3507)\end{array}$ \\
\hline IA_GS_Decile & $\begin{array}{l}-0.8730^{\mathrm{a}} \\
(0.0826)\end{array}$ & $\begin{array}{l}-0.8343^{a} \\
(0.0806)\end{array}$ & $\begin{array}{l}-2.2892^{\mathrm{a}} \\
(0.1980)\end{array}$ & $\begin{array}{l}-2.1865^{\mathrm{a}} \\
(0.1932)\end{array}$ & $\begin{array}{r}-0.1087^{a} \\
(0.0139)\end{array}$ & $\begin{array}{l}-0.1076^{\mathrm{a}} \\
(0.0135)\end{array}$ \\
\hline IA_GS_Decile $*$ Civil & $\begin{array}{c}0.8869^{\mathrm{a}} \\
(0.1598)\end{array}$ & & $\begin{array}{c}2.4323^{\mathrm{a}} \\
(0.3835)\end{array}$ & & $\begin{array}{c}0.1244^{\mathrm{a}} \\
(0.0268)\end{array}$ & \\
\hline IA_GS_Decile * Low Protection & & $\begin{array}{c}0.8295^{\mathrm{a}} \\
(0.1688)\end{array}$ & & $\begin{array}{c}2.3746^{a} \\
(0.4041)\end{array}$ & & $\begin{array}{r}0.1165^{\mathrm{a}} \\
(0.0283)\end{array}$ \\
\hline Tax Advantage of Div & $\begin{array}{c}3.7703 \\
(4.0724)\end{array}$ & $\begin{array}{c}4.0120 \\
(5.5198)\end{array}$ & $\begin{array}{c}7.7032 \\
(10.9624)\end{array}$ & $\begin{array}{c}7.2467 \\
(11.1096)\end{array}$ & $\begin{array}{c}1.4371^{\mathrm{a}} \\
(0.4819)\end{array}$ & $\begin{array}{l}1.6823^{\mathrm{c}} \\
(0.9124)\end{array}$ \\
\hline Observations & 4,077 & 4,077 & 4,076 & 4,076 & 4,077 & 4,077 \\
\hline$\chi^{2}$ & 141.26 & 117.12 & 134.59 & 129.53 & 147.28 & 77.82 \\
\hline Prob $>\chi^{2}$ & 0.0000 & 0.0000 & 0.0000 & 0.0000 & 0.0000 & 0.0000 \\
\hline
\end{tabular}

$\mathrm{a}=$ Significant at $1 \%$ level; $\mathrm{b}=$ Significant at $5 \%$ level; $\mathrm{c}=$ Significant at $10 \%$ level. 


\section{Appendix 1: Construction of the Tax Advantage of Dividends}

The appendix presents the raw data used to calculate the tax preference of dividends for each country. We use the tax rates faced by local residents who acquire minority stakes in publicly traded securities and hold their investments long enough to qualify for long-term capital gains tax rates. Furthermore, we assume that the effective tax rate on capital gains is equivalent to one-fourth of the nominal rate (Poterba, 1987). Finally, we combine federal and local taxes whenever possible. In order to compute the tax parameter, it is helpful to use the criteria proposed by King (1977) and group the tax systems of the countries in our sample in three broad categories:

1. The classical system: Personal and corporate taxation are independent of each other and shareholders receive no compensation for taxes paid at the corporate level. Specifically, the company pays a flat rate of corporate tax on profits (ie, distributed and undistributed income are taxed at the same rate) and shareholders pay income tax on dividend receipts. Accordingly, the value to an investor of one dollar in earnings distributed in the form of dividends is equal to $\left(1-\tau_{\text {corp }}\right) *\left(1-\tau_{\text {div }}\right)$, where $\tau_{\text {corp }}$ is the corporate tax rate on income and $\tau_{\text {div }}$ is the personal tax rate on dividend receipts. Similarly, the value to an investor of one dollar in earnings retained inside the firm is given by $\left(1-\tau_{\text {corp }}\right) *\left(1-\tau_{\text {cap }}\right)$, where $\tau_{\text {cap }}$ is the effective personal tax rate on capital gains. Therefore, the dividend tax preference parameter (defined as the ratio of the value earnings distributed as dividends versus earnings retained inside the firm $)$ is given by $\left(1-\tau_{\text {div }}\right) /\left(1-\tau_{\text {cap }}\right)$.

2. The two-rate system: The corporate tax rate on earnings distributed as dividends is lower than on retained earnings to mitigate the tax-advantage of retained earnings in the classical system. Accordingly, the value to an investor of one dollar in earnings distributed in the form of dividends is equal to $\left(1-\tau_{\text {dist }}\right) *\left(1-\tau_{\text {div }}\right)$, where $\tau_{\text {dist }}$ is the corporate tax rate on distributed income. Similarly, the value to an investor of one dollar in earnings retained inside the firm is given by $\left(1-\tau_{\text {ret }}\right) *\left(1-\tau_{\text {cap }}\right)$, where $\tau_{\text {ret }}$ is the corporate tax rate on retained earnings. Thus, the dividend tax preference parameter is given by $\left(1-\tau_{\text {dist }}\right) *\left(1-\tau_{\text {div }}\right) /\left(\left(1-\tau_{\text {ret }}\right) *\left(1-\tau_{\text {cap }}\right)\right)$. In practice, the pure two-rate system is implemented rarely in our sample of countries. In fact, only two countries in our sample have different tax rates for retained earnings and dividends: Germany and South Africa. However, in South Africa taxes on dividends are higher than on retained earnings contrary to the motivation behind the two-rate system, $\left(\tau_{\mathrm{div}}=49 \% \mathrm{vs} \tau_{\mathrm{ret}}=40 \%\right)$. Interestingly, dividends in Germany are not only taxed at a lower corporate rate but shareholders are allowed to credit taxes paid by corporations on distributions to offset personal taxes in the same way as in the imputation system.

3. The Imputation System: Shareholders receive credit for taxes paid by the company on earnings distributed as dividends. These credits may be used to offset shareholder's tax liability. Part of the corporate tax liability on distributed profits is "imputed" to shareholders and regarded as a pre-payment of their personal income tax. In the most frequent version of the imputation system, dividends are regarded as having borne personal tax at the "imputation" rate $\tau_{\text {imp }}$ and shareholders are liable only for the difference between their marginal tax rates on personal income and the imputation rate (ie, they pay taxes on dividend receipts at the rate $\tau_{\mathrm{div}} \tau_{\mathrm{imp}}$ ). Accordingly, the value to an investor of one dollar in earnings distributed in the form of dividends is equal to $\left(1-\tau_{\text {corp }}+\tau_{\text {imp }}\right) *\left(1-\tau_{\text {div }}\right)$. Hence, the dividend tax preference parameter is given by $\left(1-\tau_{\text {dist }}+\tau_{\text {imp }}\right) *\left(1-\tau_{\text {div }}\right) /\left(\left(1-\tau_{\text {ret }}\right) *\left(1-\tau_{\text {cap }}\right)\right)$.

Less frequently, the operation of the system is defined in terms of a tax credit rate $\tau_{\text {cred }}$ and not an imputation rate. In countries that rely on tax credits, shareholders are liable for the difference between the personal taxes owed on dividends-cum-tax-credit received and the tax credit (ie, they pay taxes on dividend receipts at the rate $\left(1+\tau_{\text {cred }}\right) * \tau_{\text {div }^{-}}$ $\tau_{\text {cred. }}$ ). In such cases, we re-express $\tau_{\text {cred }}$ in terms of its associated $\tau_{\text {imp }}$ and use the formula for the imputation system described previously. 


\begin{tabular}{|c|c|c|c|c|c|c|c|c|}
\hline & (A) & (B) & (C) & (D) & (E) & (G) & (H) & \\
\hline Country & $\begin{array}{c}\text { Corp Tax } \\
\text { Undistrib. } \\
\text { Profits }\end{array}$ & $\begin{array}{c}\text { Corp Tax } \\
\text { Distrib. } \\
\text { Profits }\end{array}$ & $\begin{array}{l}\text { Personal Tax } \\
\text { Cap Gains }\end{array}$ & $\begin{array}{l}\text { Personal Tax } \\
\text { Dividends }\end{array}$ & $\begin{array}{c}\text { Imputation } \\
\text { Rate }\end{array}$ & $\begin{array}{l}\text { Value \$1 Div } \\
(1-\mathrm{B}+\mathrm{E})^{*}(1-\mathrm{D})\end{array}$ & $\begin{array}{c}\text { Value \$1 Cap } \\
\text { Gains } \\
(1-\mathrm{A})^{*}(1-\mathrm{C} / 4)\end{array}$ & $\begin{array}{c}\text { Div Tax } \\
\text { Preference } \\
(\mathrm{G} / \mathrm{H})\end{array}$ \\
\hline Argentina & 0.30 & 0.30 & 0.00 & 0.00 & 0.00 & 0.70 & 0.70 & 1.00 \\
\hline Austria & 0.34 & 0.34 & 0.00 & 0.22 & 0.00 & 0.51 & 0.66 & 0.78 \\
\hline Belgium & 0.40 & 0.40 & 0.00 & 0.26 & 0.00 & 0.44 & 0.60 & 0.74 \\
\hline Denmark & 0.34 & 0.34 & 0.40 & 0.40 & 0.00 & 0.40 & 0.59 & 0.67 \\
\hline Finland & 0.25 & 0.25 & 0.25 & 0.25 & 0.25 & 0.75 & 0.70 & 1.07 \\
\hline France $^{1}$ & 0.33 & 0.33 & 0.19 & 0.60 & 0.33 & 0.40 & 0.63 & 0.63 \\
\hline Germany $^{2}$ & 0.54 & 0.41 & 0.00 & 0.53 & 0.25 & 0.39 & 0.46 & 0.86 \\
\hline Indonesia & 0.35 & 0.35 & 0.30 & 0.30 & 0.00 & 0.46 & 0.60 & 0.76 \\
\hline Italy $^{3}$ & 0.52 & 0.52 & 0.00 & 0.51 & 0.27 & 0.37 & 0.48 & 0.77 \\
\hline Japan & 0.52 & 0.52 & 0.26 & 0.35 & 0.00 & 0.31 & 0.45 & 0.70 \\
\hline S. Korea & 0.34 & 0.34 & 0.00 & 0.22 & 0.00 & 0.52 & 0.66 & 0.79 \\
\hline Mexico & 0.41 & 0.41 & 0.00 & 0.00 & 0.00 & 0.59 & 0.59 & 1.00 \\
\hline Netherlands & 0.35 & 0.35 & 0.00 & 0.60 & 0.00 & 0.26 & 0.65 & 0.40 \\
\hline Norway & 0.28 & 0.28 & 0.28 & 0.28 & 0.28 & 0.72 & 0.67 & 1.08 \\
\hline Philippines $^{4}$ & 0.35 & 0.35 & 0.20 & 0.00 & 0.00 & 0.65 & 0.62 & 1.05 \\
\hline Portugal & 0.40 & 0.40 & 0.10 & 0.30 & 0.22 & 0.57 & 0.59 & 0.97 \\
\hline Spain & 0.35 & 0.35 & 0.56 & 0.56 & 0.26 & 0.40 & 0.56 & 0.72 \\
\hline Sweden & 0.28 & 0.28 & 0.13 & 0.00 & 0.00 & 0.72 & 0.70 & 1.03 \\
\hline Switzerland & 0.34 & 0.34 & 0.00 & 0.44 & 0.00 & 0.37 & 0.66 & 0.56 \\
\hline Taiwan & 0.25 & 0.25 & 0.00 & 0.40 & 0.00 & 0.45 & 0.75 & 0.60 \\
\hline Turkey & 0.27 & 0.27 & 0.00 & 0.10 & 0.00 & 0.66 & 0.73 & 0.90 \\
\hline Civil Law Mean & 0.36 & 0.35 & 0.13 & 0.30 & 0.09 & 0.52 & 0.62 & 0.81 \\
\hline Australia & 0.33 & 0.33 & 0.47 & 0.47 & 0.33 & 0.53 & 0.59 & 0.90 \\
\hline Canada $^{5}$ & 0.44 & 0.44 & 0.40 & 0.36 & 0.14 & 0.45 & 0.51 & 0.89 \\
\hline Hong Kong & 0.18 & 0.18 & 0.00 & 0.00 & 0.00 & 0.83 & 0.83 & 1.00 \\
\hline India & 0.52 & 0.52 & 0.22 & 0.45 & 0.00 & 0.27 & 0.46 & 0.58 \\
\hline Ireland & 0.40 & 0.40 & 0.40 & 0.48 & 0.20 & 0.42 & 0.54 & 0.77 \\
\hline Malaysia & 0.30 & 0.30 & 0.00 & 0.32 & 0.00 & 0.48 & 0.70 & 0.68 \\
\hline New Zealand & 0.33 & 0.33 & 0.00 & 0.33 & 0.33 & 0.67 & 0.67 & 1.00 \\
\hline
\end{tabular}




\begin{tabular}{|c|c|c|c|c|c|c|c|c|}
\hline & (A) & (B) & (C) & (D) & (E) & (G) & $\overline{(\mathrm{H})}$ & \\
\hline Country & $\begin{array}{l}\text { Corp Tax } \\
\text { Undistrib. } \\
\text { Profits }\end{array}$ & $\begin{array}{c}\text { Corp Tax } \\
\text { Distrib. } \\
\text { Profits }\end{array}$ & $\begin{array}{c}\text { Personal Tax } \\
\text { Cap Gains }\end{array}$ & $\begin{array}{l}\text { Personal Tax } \\
\text { Dividends }\end{array}$ & $\begin{array}{l}\text { Imputation } \\
\text { Rate }\end{array}$ & $\begin{array}{l}\text { Value } \$ 1 \text { Div } \\
(1-B+E)^{*}(1-D)\end{array}$ & $\begin{array}{c}\text { Value \$1 Cap } \\
\text { Gains } \\
(1-\mathrm{A}) *(1-\mathrm{C} / 4)\end{array}$ & $\begin{array}{c}\text { Div Tax } \\
\text { Preference } \\
(\mathrm{G} / \mathrm{H})\end{array}$ \\
\hline Singapore & 0.27 & 0.27 & 0.00 & 0.30 & 0.27 & 0.70 & 0.73 & 0.96 \\
\hline South Africa & 0.40 & 0.49 & 0.00 & 0.00 & 0.00 & 0.51 & 0.60 & 0.85 \\
\hline Thailand & 0.30 & 0.30 & 0.00 & 0.37 & 0.30 & 0.63 & 0.70 & 0.90 \\
\hline United Kingdom & 0.33 & 0.33 & 0.40 & 0.40 & 0.17 & 0.50 & 0.60 & 0.83 \\
\hline United States & 0.42 & 0.42 & 0.36 & 0.47 & 0.00 & 0.31 & 0.53 & 0.58 \\
\hline Common Law Mean & 0.35 & 0.36 & 0.19 & 0.33 & 0.14 & 0.53 & 0.62 & 0.85 \\
\hline
\end{tabular}

${ }^{1}$ Dividends in France are grossed up by $50 \%$ for tax purposes and the individual can claim credit for up to $50 \%$ of the cash amount of the dividend.

${ }^{2}$ Dividends in Germany are grossed up by $3 / 7$ for tax purposes and the individual can claim credit for up to $3 / 7$ of the cash amount of the dividend.

${ }^{3}$ Dividends in Italy are grossed up by $56.25 \%$ for tax purposes and the individual can claim credit for up to $56.25 \%$ of the cash amount of the dividend.

${ }^{4}$ Capital gains on investments in Malaysian non-traded companies are taxed at 20\%. However, investments in publicly traded companies are exempt from capital gains but pay a sales tax of $0.25 \%$ on each trade.

${ }^{5}$ Dividends in Canada are grossed up by $25 \%$ for tax purposes and the individual can claim credit for up to $25.0 \%$ of the cash amount of the dividend. The $14 \%$ imputation rate is based on the highest combined federal and provincial marginal tax rates for Ontario (35.92\%).

Sources: Worldwide Corporate Tax Guide and Directory, Ernst and Young, 1994.

Worldwide Personal Tax Guide, Ernst and Young, 1994.

Corporate Taxes. A Worldwide Summary, Price Waterhouse, 1995.

Individual Taxes. A Worldwide Summary. Price Waterhouse, 1995.

Taxing Profits in a Global Economy. Domestic and International Issues. OECD, 1991.

Whenever Ernst and Young and Price Waterhouse differed, we relied on the source that presented more details. We used the OECD source only for Switzerland. 